\title{
Journal of Environmental Science and Sustainable Development
}

7-31-2019

\section{A POLYCENTRIC WASTE MANAGEMENT SYSTEM IN THE KATHMANDU VALLEY, NEPAL}

Sanae Ito

National Institute for the Humanities; Graduate school of Asian and African Studies(ASAFAS), Kyoto

University Yoshidahonmachi, Sakyo-ku, Kyoto 606-8501 Japan, ito-s@asafas.kyoto-u.ac.jp

Follow this and additional works at: https://scholarhub.ui.ac.id/jessd

Part of the Environmental Studies Commons

\section{Recommended Citation}

Ito, Sanae (2019). A POLYCENTRIC WASTE MANAGEMENT SYSTEM IN THE KATHMANDU VALLEY, NEPAL. Journal of Environmental Science and Sustainable Development, 2(1), 61-74.

Available at: https://doi.org/10.7454/jessd.v2i1.30

This Review Article is brought to you for free and open access by the School of Environmental Science at UI Scholars Hub. It has been accepted for inclusion in Journal of Environmental Science and Sustainable Development by an authorized editor of UI Scholars Hub. 


\title{
A POLYCENTRIC WASTE MANAGEMENT SYSTEM IN THE KATHMANDU VALLEY, NEPAL
}

\section{Sanae Ito}

National Institute for the Humanities, Graduate School of Asian and African Studies (ASAFAS), Kyoto University, Yoshida-honmachi, Sakyo-ku, Kyoto 606-8501, Japan

*Corresponding author: e-mail: ito-s@asafas.kyoto-u.ac.jp

(Received: 22 May 2019; Accepted: 29 July 2019; Published: 31 July 2019)

\begin{abstract}
This study examined contemporary waste management systems in the Kathmandu Valley, Nepal. Many waste management projects have been launched in Nepal since the 1980s. Recent projects have targeted citizens' awareness. Governments and international donor agencies have reported that awareness of waste management has not yet been achieved. Previous studies have discussed the failures of waste management in Nepal, while others have pointed out the negative impacts of waste management projects on the local community. In this paper, an alternative framework for understanding the waste issue from an anthropological perspective is provided through a case study. Specific attention was paid to how and by whom waste is managed, and how all actors interact to develop a waste management system in the Kathmandu Valley. In this study, ethnographical research methods were employed. This study revealed that, despite government claims to the contrary, people were already aware of waste problems. Activities of those who were "aware" of the waste problems did not properly correspond with the proposed waste management projects. People developed waste management businesses by themselves. In addition, the practical waste management system in Nepal is much more complicated and informal than government and donor agency's expectations. Practically, waste management in the Kathmandu Valley was accomplished through a multi-faceted development of a complicated and fragile system. The system is not perfect, but it functions as an effective polycentric system.
\end{abstract}

Keywords: community-based organizations; Nepal; solid waste management; polycentric system; development

\section{Introduction}

In the Kathmandu Valley, waste has remained a development-related problem. Many waste management projects have been launched in recent decades, yet the problem remains unsolved. Policy scholars have blamed this recurring issue on governmental weakness. They have posited that the weakness of the Nepali government acts as a bottleneck of failed waste management projects and that a strong government may fix the problem (Dangi, Urynowicz, \& Belbase, 2013; Tuladhar, 1996). Is this true? Have waste management projects truly failed? Is a strong government necessary to manage waste? This article addresses these questions by employing ethnographical research methods. 


\subsection{Research Area}

Nepal is a landlocked country situated between China to its north and India to its south. Its environment is diverse, from rain forests to the south to the Himalayas - which include the tallest mountain in the world, Mt. Everest - to the north. Nepal's population is around 30,000,000. There are many ethnic groups and castes, but their numbers differ across studies. According to a recent census, the number of ethnic and caste groups is estimated to be 78 (Central Bureau of Statistics, 2012).

Nepal has experienced political turbulence, especially following the democratization movement in 1990. There was an armed struggle between the Nepalese government and Maoists from 1996 to 2006. This political turbulence substantially impacted the government. For example, there were no mayors or local assemblies from 1998 to 2017. Urbanization and rapid lifestyle change were among the factors that affected waste management in the Kathmandu Valley. These led to drastic changes in the composition and amount of waste. The government-managed waste management system frequently intervened, and waste was scattered throughout urban areas.

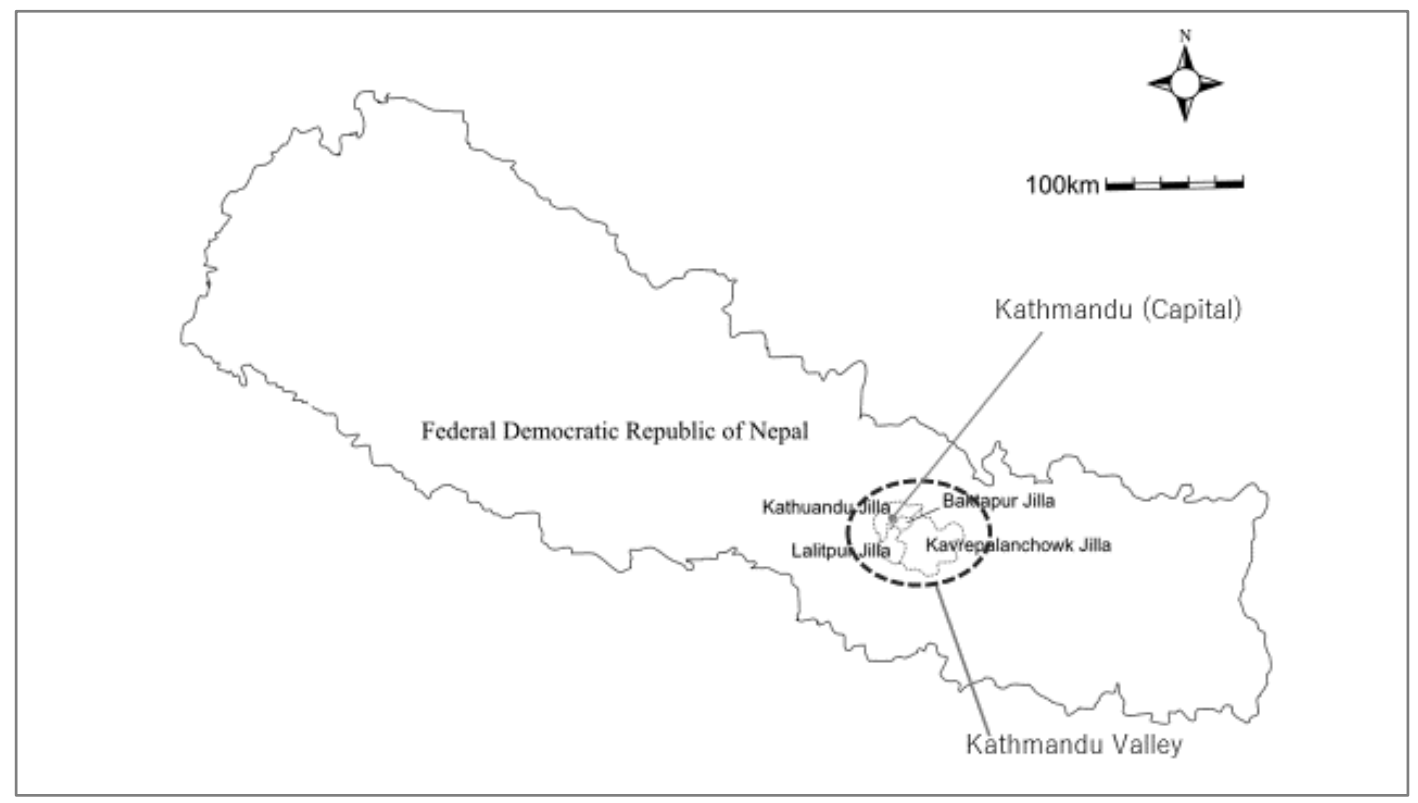

Figure 1. Map of the Kathmandu Valley

The area primarily examined in this study is a community called P Village (Figure 2). $\mathrm{P}$ Village is a suburban Newar community in Kathmandu Valley that is located $7 \mathrm{~km}$ southwest of Kathmandu (Kirti Adhyayan tatha Anusandhān Mandhal, 2017). The population is approximately 4,000. The Newar are the major ethnic group within the Kathmandu Valley. They are known to have established cities and villages in the Kathmandu Valley as early as 5 AD, perhaps even earlier (Nepali, 2015; Toffin, 2007). The Newar have a caste system. Beginning in the 1990s, many kinds of participatory development projects, including waste management projects, were initiated in P Village. 


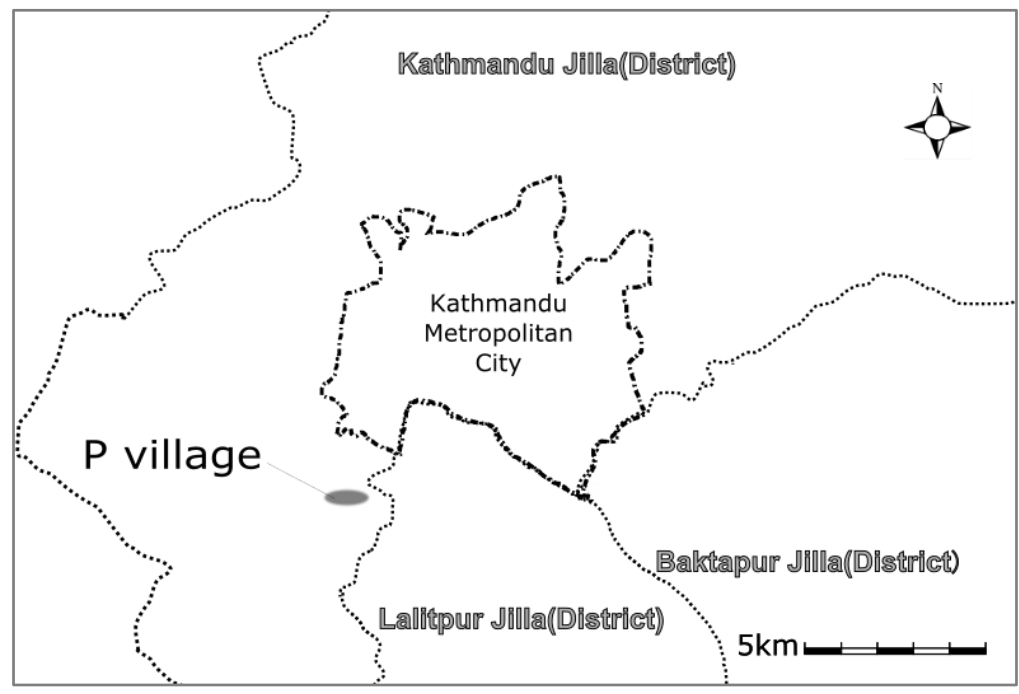

Figure 2. The location of $\mathrm{P}$ village

\subsection{Anthropological Studies on Waste}

Policy science researchers generally consider solid waste-for example, food, papers, metals, snack packaging, plastic bottles, and electric waste - to fall within the domain of government regulation due to the risk of pollution. Anthropologists have criticized this assumption from several perspectives (Reno, 2015). Alexander \& Reno (2012) noted that no governments manage waste with practical efficacy, thus it is necessary to examine real-world waste management activities. Some anthropologists have also highlighted that "waste" does not refer to primary waste; these arguments define waste as context-dependent. An object may become waste if it is not useful to one person, but the same material may still be useful or valuable for others. These authors have insisted upon the importance of examining waste from perspectives of materiality (Campkin, 2013; Reno, 2014).

Waste markets and their related labor forces comprise another aspect of the problem. Some anthropologists have stated that the market facilitates creativity and the possibility for innovation. For example, Norris (2012) discussed how workers in recycling factories produce new economic and social values. Other researchers have focused on the discrimination and marginalization of waste workers (Gill, 2010; Fredericks, 2012; Nguyen, 2014; Sekine \& Suzuki, 2017). Recently, waste workers' movements has garnered scholarly interest (Kuppinger, 2014).

\subsection{Waste in South Asia and Nepal}

Dirtiness and purity are often invoked in anthropological discussions on waste. Douglass (1966) revealed that the notion of dirtiness was not derived from sanitation; she stated that people experienced dirtiness when an object crossed borders and became ambiguous. For example, people consider human bodily waste to be dirty and dangerous due to its ambiguous connection to the human body. It is already apart from the body, but it still maintains characteristics of the body.

The majority of South Asia — especially regions that retain the influence of Hinduismhave caste groups that are designated to perform waste management. This caste is considered to be one of the lowest of the caste groups. Higher castes had thought that they should not 
touch them. Scholars who have studied caste systems have reported that caste hierarchy is decided by subsistence transactions related to the human body (Dumont, 1970; Marriott, 1976).

In Kathmandu Valley, human bodily waste and waste from rituals are both referred to as "jutho." The Newar people, the major ethnic group within the research area, believe that jutho must be treated in a particular manner (Levy, 1990; Tuladhar, 1996). People in the Kathmandu Valley also use the word "phohar" to indicate waste. Phohar can be used both as a noun and as an adjective. Jutho is invoked during discussions about dirtiness and purity, whereas phohar is only used in discussions about the materiality of waste. In contemporary Nepal, waste has two dimensions, and is managed contextually.

In the caste system of the Newar, there is a sweeper caste, which is considered to be one of the lowest castes. They are expected to sweep streets and perform many kinds of ritualistic duties. For example, leftover food from ritual ceremonies of other caste groups are to be managed by this caste (Gellner, 1999).

The concept of uncleanliness was developed by modernists and nationalists in India in the colonial era. They had close relationships with colonial governments, and some had even traveled to European countries. They began to perceive of Indian streets as "dirty" and blamed this dirtiness on citizens' lack of awareness (Chakrabarty, 2002). Modernists and nationalists in India had begun integrating the modern governance concepts of modern Europe into their sociopolitical frameworks. In Europe, especially following the emergence of modern nation-states, sanitation maintenance became the responsibility of governments. Citizens were also meant to cooperate with governmental work to maintain sanitation (Alexander \& Reno, 2012). From this perspective, modernists and nationalists believed that waste on the streets indicated a lack of citizenship of Indian people.

In Nepal, this modern concept of governmental responsibility for waste management arrived after the restoration of the Shah monarchy in 1951. Nepal had never been colonized and retained a closed-door policy until 1951; therefore, Nepal's rulers had not aimed to achieve a modern nation-state as had been established in European countries (Liechty, 2010). After 1951, the country began to transition to a modern nation-state, establishing many laws and acts for this purpose. The Nagar Panchayat Act (Municipality Act) was one such newly established act stating that "hazardous waste on the streets should be managed by local government officials" (Tuladhar, 1998). Most local governments in the Kathmandu Valley intended to follow this regulation by employing those within the sweeper caste as waste workers (Tanaka, 2001).

After the 1980s, international development agencies and Nepali governments began initiating waste management projects. Many early projects focused on local governments' central position in waste management. After the 2000s, when the trend of participatory development was observed in the field of development, the target of waste management projects shifted from government officials to citizens (Nippon Koei \& Yachiyo Engineering, 2005). The same tendency of Indian modernists and nationalist arrived in Nepal. Similar to these Indian modernists and nationalists, government officials and international donor agencies began to emphasize citizens' "awareness" of waste management problems. River clean-up campaigns can be considered under this tendency toward a keen "modernization" in the Kathmandu Valley (Rademacher, 2011). 
These waste management projects did not include waste management systems prior to 1951. For example, awareness programs mentioned phohar but never mentioned jutho (Sthaniya Prayāsdwārā Shahari Kshetra Bikās Kāryakram, 2010). Yamagmi (2007) blamed the concept of jutho for sometimes hindering awareness projects. Kasai (2012) criticized projects from another perspective. She said that waste management projects were designed with the assumption that waste and waste management problems were the same globally, hence pre-designed projects could be initiated everywhere. In Nepal, however, she reported that these pre-designed projects destroyed local systems of waste management like sāh gāh Sāh găh, a kind of composting system that the Newar people maintained for several centuries, has recently begun to disappear (Bajracharya \& Shrestha, 2009).

\subsection{Problems}

Previous studies have primarily discussed the failures of waste management systems on the assumption that waste should be managed thorough government-led systems (Tuladhar, 1996; Yamagami, 2007), while others have simply posited that waste management projects have negatively impacted the local community (Kasai, 2012). In this paper, the limitations of both perspectives are explored to provide an alternative framework for understanding the waste issue in Nepal. The primary problem with the former statement is that it is founded upon an ignorance of reality, and thus ignores the problems of actual systems and the role of non-governmental bodies in waste management. The latter position assumes that community is necessarily traditional and static. Anthropologists of development have explained that people are not objects that can be changed by development projects. Rather, they interact with projects and interpret meanings and values within specific contexts (Leve, 2007; Leve, 2009; Fujikura, 2013). Through the case studies, I will demonstrate that this interpretation is reflected in waste management projects in Nepal, also. And through this process, a polycentric waste management system is established. I utilize Ostrom (2010) notion of a polycentric systems. She examined the management systems of commons from many countries and found that systems characterized by many decision-making subjects were more efficient than hierarchical systems.

This paper discusses the possibility of an alternative to a government-led waste management system from an anthropological perspective through a case study of practical waste management in the Kathmandu Valley. I specifically focus on by whom and how waste is managed in the Kathmandu Valley.

\section{Methods}

In this study, ethnographical research methods were employed-primarily, participatory observation and non-constructed and semi-constructed interviews to reveal an actual waste management system in the suburban areas of Kathmandu Valley. A literature review and examination of government and international agency documents are also included. This research was conducted intermittently in the Kathmandu Valley, Nepal, from 2014 to 2018, and spanned 348 days in total. For the majority of the study period, I lived in P village, and participated in the activities of the villagers therein. These activities were not limited to waste-related ones. I chose P village as the main research area because it is one where the population is rapidly growing. Thus, I observed several waste management organizations and 
waste management companies. I also conducted interviews with government officials, international agencies, and waste workers.

\section{Results and Discussion}

\subsection{A Waste Management Project in P Village}

First, this section will detail conflicts between local concepts and an awareness project, which was carried out under the assumption that the government's initiative and modern methods are necessary for waste disposal.

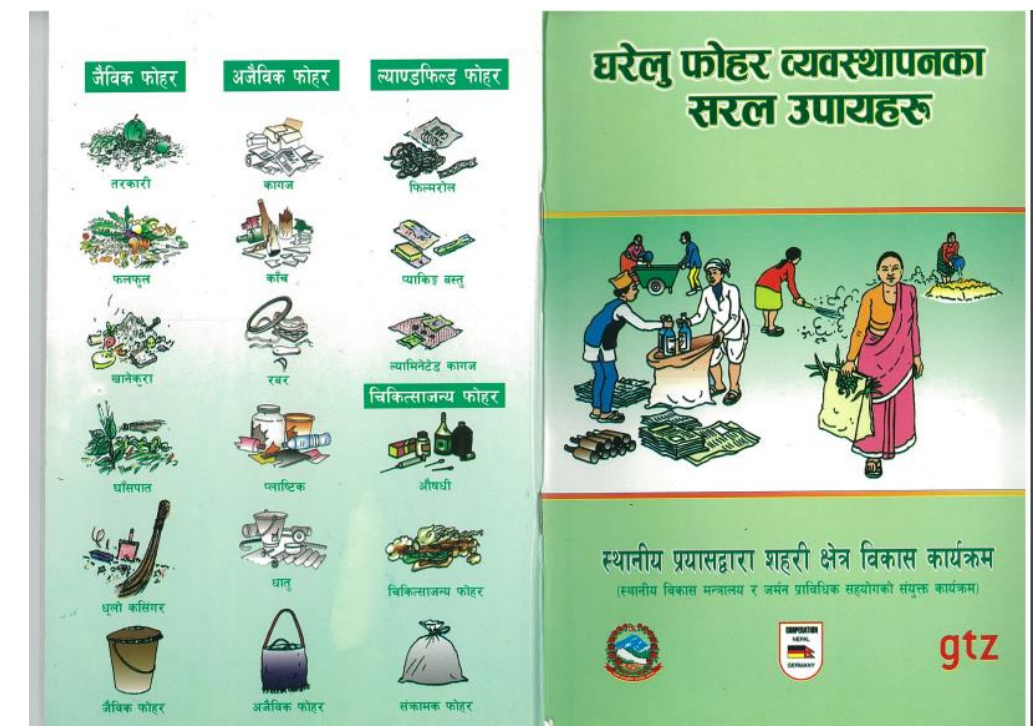

Figure 3. Front cover of a waste management training textbook

A waste management project was conducted in $\mathrm{P}$ village. The project was initiated by the local government, supported by a German donor agency called Deutshe Gesellschaft Für Technische Zusammenarbeit (Gtz). Figure 3 shows the book published by Gtz. It includes a clear outline of tasks that "good citizens" perform, and appropriate techniques that they should use. For example, a lady uses a cloth bag, rather than a plastic bag. Another lady is sweeping, and a man separates waste. Another man is making compost fertilizer from organic waste. A cluster-based task is stated in the inside cover (Table 1). The textbook also stated that "local governments have the responsibility to manage waste," and citizens should cooperate by performing specific roles.

I observed a waste management program on February 13, 2012, based on this textbook that targeted women in P Village. It was a two-day program initiated by local government officials with a local women's group. The main purpose of the program was to encourage women's "awareness" about waste management problems. The 3R concept (reduce, reuse, recycle) was introduced. Most of the second day was used to explain, in detail, how to use a compost bin in detail. The compost bin is a tool for household composting (Figure 4). The officer teaching the program never used the term jutho, but insisted that it was prohibited to put leftover food into a compost bin: “...put the peel and leaves of vegetables in a compost bin. If you do so, you can make compost fertilizer. Do not put uneaten or cooked ingredients in a compost bin. It is because rats come and make a hole on a surface of a compost bin. It is 
important to cook and serve food so that there are no leftovers. It leads to saving money as well as saving food."

Table 1. List describing preferred citizen action

\section{$\langle$ What we should do in managing phohar mailā $>$}

\begin{tabular}{|l|}
\hline As an individual \\
\hline Let's habituate to keep phohars, instead of throwing them away. \\
\hline Let's go to the market with a bag. Try not to use plastic bags as much as possible. \\
\hline Let's buy products with minimal packaging. \\
\hline Let's separate to collect degradable phohars and non-degradable phohars. \\
\hline Let's compost in the house. \\
\hline Let's sell non-degradable phohars to a collection company. \\
\hline Let's habituate to tell at least one neighbor what learned in this program. \\
\hline Let's find solutions to problems rather than doing problems. \\
\hline As a group \\
\hline Let's make it a habit to recycle. Try to not make unnecessary phohars. \\
\hline Let's establish a joint management program of phohar with group members. \\
\hline Let's use as much as possible. \\
\hline Let's find solutions to problems rather than doing problems. \\
\hline As a society \\
\hline Let's develop a method to segregate and collect recyclables in a society. \\
\hline $\begin{array}{l}\text { Let's encourage community members to manage phohar in the house as much as } \\
\text { possible. }\end{array}$ \\
\hline $\begin{array}{l}\text { Let's encourage schools and community groups in a community to create an } \\
\text { environmental club and hold events related to phohar management. }\end{array}$ \\
\hline Let's plan an awareness event on environmental day. \\
\hline
\end{tabular}

(Source: Sthaniya Prayāsdwārā Shahari Kshetra Bikās Kāryakram, 2010)

Neither the program nor the textbook mentioned juṭho nor $s \bar{a} h \underline{g} \bar{a} h \underline{h}$. Instead, they urged people to fulfill cluster-based roles, which were presented in the textbook as being the roles of a wise citizen. 


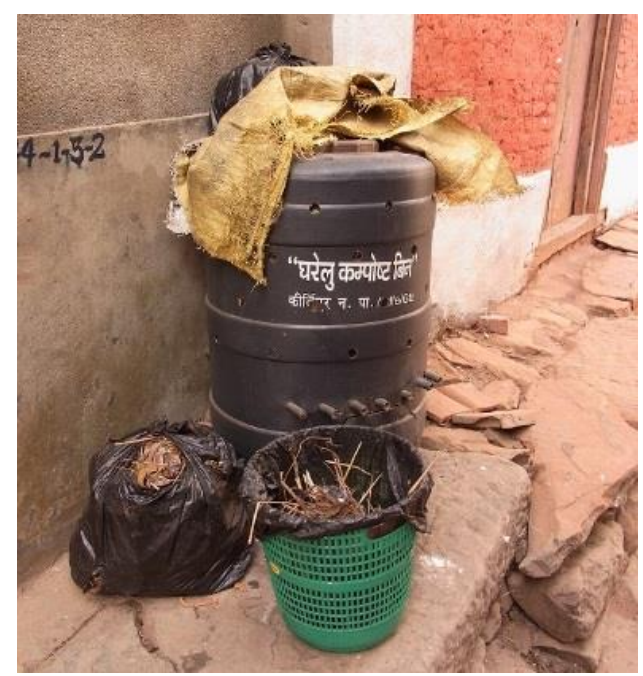

Figure 4. Compost bin

\subsection{Private Sectors}

This section details the role of the private sector in the practical waste management system in Nepal, which has been omitted in previous researches as mentioned in 1.4. Figure 6(a) shows the proposed waste management system expected by the government and donor agencies, and Figure 6(b) describes the practical waste management system. There are various actors who manage waste. When waste is generated, contract waste collectors typically collect it while consumers can sell valuables to waste buyers. There are dealers of valuable waste such as paper, metals, bins, and so on. They sell them again to larger waste dealers or recycling factories.

Waste that cannot be sold is brought into government-controlled transfer stations or final disposal sites to be placed in landfills. Uncollected waste on the streets is also brought to final disposal sites by government workers. Throughout these processes, waste pickers look for valuables within collected waste. Governments do not control this entire process. Rather, a kind of informal economy has emerged around waste management. 
a
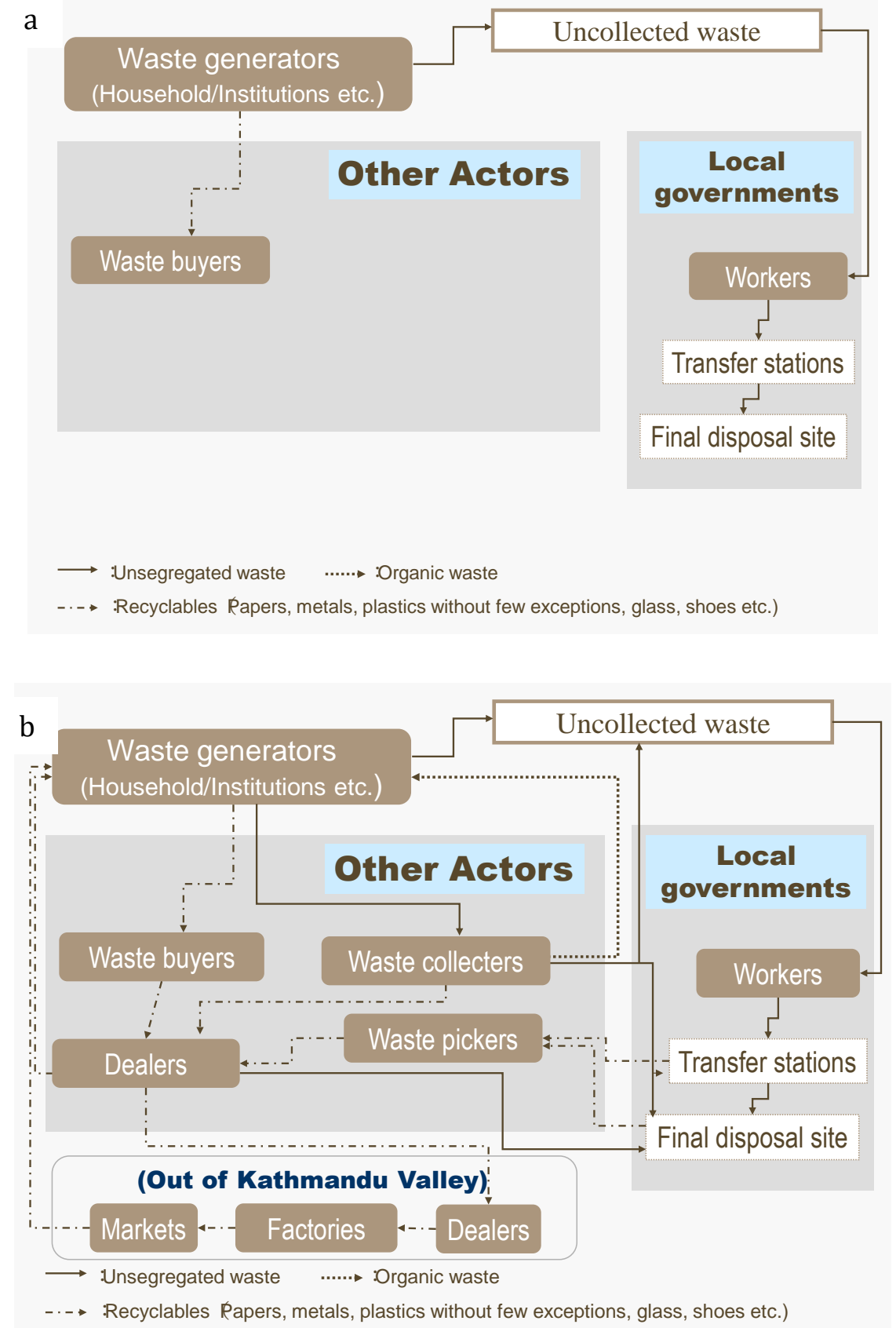

Figure 6. (a) Proposed waste management system and (b) practical waste management system

\subsection{Community-based Organized Waste Management Practices}

Previous research has highlighted the vulnerability of the communities that were targeted by waste management projects (Kasai, 2012). These studies reported that these communities faced a risk by being forced to change. In this section, I criticize this statement through studying a case of a community-based organization.

In most waste management systems, the community is expected to simply function as a waste generator. I identified a community-based organization that was involved in activities beyond those typically expected of community members called the Society for P Village Environment Conservation (SPEC), which is based in P Village. 
This organization was established by women in the village in 2014. Most women who work for this organization have attended waste management awareness programs such as that explained in 3.2. They collect waste from households for a monthly fee. The fee is around 150 Rs (approximately 1-2 US dollars) per month. They also segregate collected waste and sell valuables while composting organics. SPEC functions as a waste collector, as shown in Figure 7. Aside from the main revenue obtained from household fees, they also generate a profit by selling valuable waste and organic waste-based fertilizer. SPEC employs eight salaried workers. Continuous negotiations with other actors was characteristic of the work of SPEC. They negotiate with dealers, government officials, and locals.

SPEC generates revenue from their activities, but they still describe their activities as "social work." Maya, a staff member of SPEC, discussed their activities on September 16, 2014: "Nepal is a rich country. Air and water in Nepal are very good. Only Nepali people's thought is poor. We started SPEC because I think we have to manage our environment by ourselves. Through SPEC, we can manage our phohar by ourselves. We can clean our village through these activities."

Women in $\mathrm{P}$ Village want to clean their environment through managing waste by themselves. To this point, they are "aware" of the problem and developed a solution. When I asked them about previous awareness programs, they all referred to the programs positively. They supported the concept that was presented in the programs. However, their activities exceeded the obligations expected of citizens in the programs. They manage their waste on a business basis rather than a household basis.

Despite the assumptions made in previous studies (Tuladhar, 1996; Yamagami, 2007), it has been proved that there is an "awareness about waste problems" in P village, which has been established with the help of case studies. Women in $\mathrm{P}$ village are keen to clean their village. However, their approach for tackling the problem is different from the cluster-based tasks that were proposed in waste management projects. Nevertheless, this "awareness" was associated with problems of modern moral and power, and therefore it was important to discuss the problems raised by Fredericks (2012).

It has been known that attempts at development in Nepal have failed (Panday, 1999). Anthropologists have pointed out that there has been "development" in Nepal, even though it has emerged in a way that the government and donor agencies never expected. Fujikura (2013) reported that the people of Nepal, who have been targeted by various development projects, had become aware of development issues as they pertain to their society. There are "cosmopolitan villagers" who think that they are more modern and developed than other villagers (Pigg, 1992). Cosmopolitan villagers and Nepali development brokers (Shrestha, 2006) who had worked for governments and international /national donor agencies had interpreted projects. All of these actors - people who were targeted by development projects, cosmopolitan villagers, Nepali development brokers, governments, and international donor agencies-achieved "development" in a Nepali context.

Analysis of the cases in chapter three reveals an identical solution. One Gtz project followed a standardized design, but the trainer in $\mathrm{P}$ village further suggested the exclusion of leftover foods from compost bins. However, he never used the word jutho to explain this idea. 
Women, who were a part of this waste management program, started to establish SPEC with the support of a national NGO. Although the extent of their actual activities surpassed that of the prior-established tasks, their motivations were similar to the ideas presented in the textbook. The project never expected the citizens to transform waste management into a business.

This is not merely a success story. SPEC had faced difficulties in maintaining their business. Discrimination among manual workers infiltrated SPEC because they had hired workers from outside of $\mathrm{P}$ village. Their business was being run in a fragile and uncontrolled waste market. The fragility and uncontrolled condition of the market brought about polycentricity. The waste management system in Nepal indicates the possibility of polycentric governance as an alternative to a government-led waste management approach, regardless of its imperfections and tendency to attract problems.

\section{Conclusion}

Waste management projects have been initiated continuously in Nepal since the 1980s. Governments and international donor agencies have reported that waste management has not yet been achieved. Recent projects have targeted citizens' awareness. However, this study reveals that people were already aware of waste problems. The activities of those who are "aware" of waste problems do not correspond with the proposed projects. People developed waste management businesses by themselves. In addition to these activities, the practical waste management system in Nepal is much more complicated and informal than government and donor agency expectations as these bodies attempt to control the whole system. Practically, waste management in the Kathmandu Valley was accomplished through the multi-faceted development of a complicated and fragile system. The system is not perfect, but it functions as an effective polycentric system.

This study is based on research conducted specifically in a suburban area of the Kathmandu Valley, especially one village, called P village. As I stated in Section 1.1, Nepal is both ecologically and ethnically diverse, so the contents of this study cannot be applied to the whole of Nepal. In addition, this paper does not cover the detailed ethnography of the sweeper caste, the waste pickers at the final disposal sites, and the waste collection companies. These will be investigated in future research. Through this future research, the polycentric waste management system in Nepal will be described more vividly.

\section{Acknowledgements}

I am grateful to the people who supported my research during my fieldwork in Nepal. Any acknowledgement would surely be incomplete without thanking the villagers of $\mathrm{P}$ village, members of the Society for P Village Environment Conservation (SPEC), the K municipality office, and any other informants. An earlier version of this paper was translated into Japanese and submitted to Kyoto University as a master's thesis in December, 2015. A part of this paper was presented at a joint seminar organized by the School of Environmental Science, University of Indonesia (SILUI), Graduate School of Asian and African Area Studies (ASAFAS), Graduate School of Global Environmental Studies (GES), Center for Southeast Asian Studies (CSEAS), and Kyoto University. I would like to thank the organizers and participants of the seminar for their helpful comments and discussions. I am thankful for the 
financial support of the Japan Society for the Promotion of the Sciences (17J02430). I would like to thank Editage for English language editing.

\section{References}

Alexander, C., \& Reno, J. (2012). Introduction. In C. Alexander \& J. Reno (Eds.), Economies of recycling: The global transformation of materials, values and social relations (pp. 134). London, UK: Zed Books. https://doi.org/10.1111/ecge.12023

Bajracharya, A. R., \& Shrestha, S. (2009). BunGaa, SaGaa, NauGaa. Kathmandu, Nepal: Visual \& Folklore Studies Office.

Campkin, B. (2013). Placing "matter out of place": Purity and danger as evidence for architecture and urbanism. Architectural Theory Review, 18(1), 46-61. https://doi.org/10.1080/13264826.2013.785579

Central Bureau of Statistics. (2012). National Population and Housing Census 2011 Major Highlights. Retrieved from https://unstats.un.org/unsd/demographicsocial/census/documents/Nepal/Nepal-Census-2011-Vol1.pdf

Chakrabarty, D. (2002). Of garbage, modernity, and the citizen's gaze. In D. Chakrabarty (Ed.), Habitations of Modernity: Essays in the Wake of Subaltern Studies (pp. 65-79). Chicago, USA: The University of Chicago Press. Retrieved from https://www.press.uchicago.edu/ucp/books/book/chicago/H/bo3626284.html

Dangi, M., Urynowicz M. A., \& Belbase, S. (2013). Characterization, generation, and management of household solid waste in Tulsipur, Nepal. Habitat International, 40, 6572. https://doi.org/10.1016/j.habitatint.2013.02.005

Douglass, M. (1966). Purity and danger: An analysis of the concepts of pollution and taboo. Routledge.

Dumont, L. (1970). Homo Hierarchicus. New Delhi, India: Oxford University Press.

Fredericks, R. (2012). Devaluing the dirty work: Gendered trash work in participatory Dakar. In C. Alexander \& J. Reno (Eds.), Economies of recycling: The global transformation of materials, values and social relations (pp. 119-142). London, UK: Zed Books. https://doi.org/10.1111/ecge.12023

Fujikura, T. (2013). Discourses of awareness: Development, social movements and the practices of freedom in Nepal. Kathmandu, Nepal: Martin Chautari.

Gellner, D. N. (1999). Low castes in Lalitpur. In D. N. Gellner \& D. Quigley (Eds.), Contested hierarchies: A collaborative ethnography of caste among the Newars of the Kathmandu Valley, Nepal (pp. 264-297). New Delhi, India: Oxford University Press. https://doi.org/10.1525/aa.2000.102.4.939

Gill, K. (2010). Of poverty and plastic: Scavenging and scrap trading entrepreneurs in India's urban informal economy. Oxford, UK: Oxford University Press.

Ito, S. (2018). The emergence of hāmro space in the Kathmandu Valley, Nepal: A study of waste management (Nepa-ru katomandoubonchi ni okeru hamurokukan no hyousyutsu: haikibutsu wo meguru jissen no jirei kara). South Asian Studies (Minamiajiakenkyu), 29, 1-27. https://doi.org/10.11384/jjasas.2017.6

Kasai, E. (2012). Packaged development aid and life change concerning the "hole" of garbage : A case study of livelihood improvement project in Kirtipur, Nepal (Pakkegika sareru kaihatsuenjyo to gomi no "ana" wo meguru seikatsuhenyou: Nepa-ru Kirutipurushi ni 
okeru seiktsukaizenpurojyekuto wo jirei toshite). Annual Review of the Institute for Advanced Social Research, 8, 55-71. http://hdl.handle.net/10236/9920

Kirti Adhyayan tatha Anusandhān Mandhal. (2017). Cultural information of Kirtipur (Kirtipurko sankripta cinarī). Kirtipur, Nepal: Namuna Printers.

Kuppinger, P. (2014). Crushed? Cairo's garbage collectors and neoliberal urban politics. Journal of Urban Affairs, 36(S2), 621-633. https://doi.org/10.1111/juaf.12073

Leve, L. G. (2007). "Failed development" and rural revolution in Nepal: Rethinking subaltern consciousness and women's empowerment. Anthropological Quarterly, 80(1), 127-172. Retrieved from https://www.jstor.org/stable/4150946

Leve, L. (2009). Women's empowerment and rural revolution: Rethinking "failed development". Dialectical Anthropology, 33(3), 345-363. Retrieved from https://www.jstor.org/stable/29790893

Levy, R. I. (1990). Mesocosm: Hinduism and the organization of a traditional Newar city in Nepal. Delhi, India: Motilal Banarsidass Publishers.

Liechty, M. (2010). Out here in Kathmandu: Modernity on the global periphery. Kathmandu, Nepal: Martin Chautari.

Marriott, M. (1976). Hindu transactions: Diversity without dualism. In B. Kapferer (Ed.), Transactions and meaning: directions in the anthropology of exchange and symbolic behavior (pp. 109-142). Philadelphia, USA: Institute for the Study of Human Issues.

Nawa, K. (2015). Pollution, ontological equality, or unthinkable series? Notes on theorization of South Asian societies by three Japanese anthropologists. International Journal of South Asian Studies, 7, 31-57. Retrieved from http://jasas.info/publications/relevance/ijsas/

Nepali, G. S. (2015). The Newars: An ethno-sociological study of a Himalayan community. Kathmandu, Nepal: Mandala Book point.

Nguyen, M. T. N. (2014). Translocal householding: Care and migrant livelihoods in a wastetrading community of Vietnam's Red River Delta. Development and Change, 45(6), 1385-1402. https://doi.org/10.1111/dech.12130

Nippon Koei \& Yachiyo Engineering. (2005). The study on the solid waste management for the Kathmandu Valley final report. Tokyo, Japan: JICA. Retrieved from http://open_jicareport.jica.go.jp/pdf/11808631_01.pdf

Norris, L. (2012). Shoddy rags and relief blankets: Perceptions of textile recycling in North India. In C. Alexander \& J. Reno (Eds.), Economies of recycling: The global transformation of materials, values and social relations (pp. 35-58). London, UK: Zed Books. https://doi.org/10.1111/ecge.12023

Ostrom, E. (2010). Polycentric systems for coping with collective action and global environmental change. Global Environmental Change, 20(4), 550-557. Retrieved from https://doi.org/10.1016/j.gloenvcha.2010.07.004

Panday, D. R. (1999). Nepal's failed development: Reflections on the mission and the maladies. Kathmandu, Nepal: South Asia Centre.

Pigg, S. L. (1992). Inventing social categories through place: Social representations and development in Nepal. Comparative Studies in Society and History, 34(3), 491-513. Retrieved from https://www.jstor.org/stable/178849

Rademacher, A. (2011). Reigning the river: Urban ecologies and political transformation in Kathmandu. Durham, UK: Duke University Press. 
Reno, J. (2014). Toward a new theory of waste: From "matter out of place" to signs of life. Theory, Culture and Society, 31(6), 3-27. https://doi.org/10.1177/0263276413500999

Reno, J. (2015). Waste and waste management. Annual Review of Anthropology, 44, 557572. https://doi.org/10.1146/annurev-anthro-102214-014146

Reno, J. (2016). Waste away: Working and living with a North American landfill. California, USA: University of California Press.

Sekine, Y., \& Suzuki., S. (2017). Marginalized people in South Asian communities: Creative practices from the below (Minamiajiakeisyakai no syuhenkasareta hitobito: sitakara no souhatsutekiseikatujissen). Tokyo, Japan: Akashishoten.

Shrestha, C. H. (2006). "They can't mix like we can": Bracketing differences and the professionalization of NGOs in Nepal. In D. Lewis \& D. Mosse (Eds.), Development brokers and translators: The ethnography of aid and agencies (pp. 195-216). Colorado, USA: Kumarian Press. Retrieved from https://www.jstor.org/stable/25548210

Sthaniya Prayāsdwārā Shahari Kshetra Bikās Kāryakram. (2010). Easy techniques for household waste management (Gharelu phohar byavasthāpānkā saral upāyaharu). Kathmandu, Nepal: Bhintunā Printers.

Tanaka, M. (2001). Who collects whom waste?: Transition of lifestyles and diversification of waste collection in the Kathmandu Municipality (Dare ga dare no gomi wo atsumerunoka?: Katomanzushi ni okeru seikatsuyoushiki no henyou to gomikaisyu no tayouka). Minamiajia no toshikankyou manajimento, 17-59.

Toffin, G. (2007). Newar society: City, village and periphery. Kathmandu, Nepal: Himal Books.

Tuladhar, B. (1996). Kathmandu's garbage: Simple solution going to waste. Studies in Nepali History and Society, 1(2), 365-393. Retrieved from http://www.martinchautari.org.np/index.php/52-publications/journals1/sinhas/272-sinhasvolume-1-number-2

Yamagami, A. (2007). Birth of garbage: Household composting and dirtiness in the Kathmandu Valley (Gomi no tanjyou: Katomanzubonchi ni okeru kateigomi taihikapurojyekuto to fujyoukan). In Abe, et al. (Eds.), Henen no Ajia (The periphery of Asia) (pp. 244-273). Tokyo, Japan: Akashishoten.

Yoshida, K. (2018). Infrastructure, boundary objects and the problem of symbolic values (Infurastorakucha/baundariobujyekuto ni okeru syouchoutekikachi no mondai:Indonesia ni okeru haikibutsutaihikagijyutsu wo megutte). Japanese Journal of Cultural Anthropology, 83(3), 385-403. https://doi.org/10.14890/jjcanth.83.3_385 